\title{
Restraint Stress Alters Nociceptin/Orphanin FQ and CRF Systems in the Rat Central Amygdala: Significance for Anxiety-Like Behaviors
}

\author{
Roberto Ciccocioppo, ${ }^{1}$ Giordano de Guglielmo, ${ }^{1}$ Anita C. Hansson, ${ }^{2}$ Massimo Ubaldi, ${ }^{1}$ Marsida Kallupi ${ }^{1,3}$ \\ Maureen T. Cruz, ${ }^{3}$ Christopher S. Oleata, ${ }^{3}$ Markus Heilig, ${ }^{4}$ and Marisa Roberto ${ }^{3}$ \\ ${ }^{1}$ School of Pharmacy, Pharmacology Unit, University of Camerino, Camerino 62032, Italy, ${ }^{2}$ Institute of Psychopharmacology at the Central Institute of \\ Mental Health, Medical Faculty Mannheim/University of Heidelberg, Heidelberg 68159, Germany, ${ }^{3}$ Committee on the Neurobiology of Addictive Disorders, \\ The Scripps Research Institute, La Jolla, California 92037, and ${ }^{4}$ National Institutes of Health/National Institute on Alcohol Abuse and Alcoholism, Bethesda, \\ Maryland 20892-1108
}

Corticotropin releasing factor (CRF) is the primary mediator of stress responses, and nociceptin/orphanin FQ (N/OFQ) plays an important role in the modulation of these stress responses. Thus, in this multidisciplinary study, we explored the relationship between the $\mathrm{N} / \mathrm{OFQ}$ and the CRF systems in response to stress. Using in situ hybridization (ISH), we assessed the effect of body restraint stress on the gene expression of CRF and N/OFQ-related genes in various subdivisions of the amygdala, a critical brain structure involved in the modulation of stress response and anxiety-like behaviors. We found a selective upregulation of the NOP and downregulation of the $\mathrm{CRF}_{1}$ receptor transcripts in the CeA and in the BLA after body restraint. Thus, we performed intracellular electrophysiological recordings of $\mathrm{GABA}_{\mathrm{A}}$-mediated IPSPs in the central nucleus of the amygdala $(\mathrm{CeA})$ to explore functional interactions between CRF and N/OFQ systems in this brain region. Acute application of CRF significantly increased IPSPs in the CeA, and this enhancement was blocked by N/OFQ. Importantly, in stress-restraint rats, baseline CeA GABAergic responses were elevated and N/OFQ exerted a larger inhibition of IPSPs compared with unrestraint rats. The NOP antagonist [Nphe1]-nociceptin(1-13)NH2 increased the IPSP amplitudes in restraint rats but not in unrestraint rats, suggesting a functional recruitment of the N/OFQ system after acute stress. Finally, we evaluated the anxiety-like response in rats subjected to restraint stress and nonrestraint rats after N/OFQ microinjection into the CeA. Intra-CeA injections of $\mathrm{N} / \mathrm{OFQ}$ significantly and selectively reduced anxiety-like behavior in restraint rats in the elevated plus maze. These combined results demonstrate that acute stress increases N/OFQ systems in the CeA and that N/OFQ has antistress properties.

\section{Introduction}

From a biological perspective, stress may be viewed as external demands placed on a living organism that in turn reacts to them with a highly dynamic combination of physiological, emotional, cognitive, and behavioral responses that have evolved to be adaptive, although they may be more or less successful in a given instance. These reactions are initially aimed at regaining a preexisting equilibrium; however, this may occur by establishing a new setpoint. This allostatic change may be viewed as only a partially successful adaptive response, which occurs in the presence of

\footnotetext{
Received June 5, 2013; revised 0ct. 2, 2013; accepted Nov. 2, 2013.

Author contributions: R.C., A.C.H., M.H., and M.R. designed research; R.C., G.d.G., A.C.H., M.K., M.T.C., C.S.O., and M.R. performed research; A.C.H. and M.U. analyzed data; R.C., M.H., and M.R. wrote the paper.

This work was supported by National Institutes of Health Grants AA017447, AA015566, AA06420, AA016985, AA014351, AA013498, and AA021491 and the Pearson Center for Alcoholism and Addiction Research. A.C.H. was supported by Deutsche Forschungsgemeinschaft HA 6102/1. We thank Dr Marian Logrip for helpful comments on the manuscript.

The authors declare no competing financial interests.

Correspondence should be addressed to either of the following: Dr. Roberto Marisa, Committee on the Neurobiology of Addictive Disorders, The Scripps Research Institute, La Jolla, CA 92037, E-mail:mroberto@scripps.edu; or Dr. Roberto Ciccocioppo, School of Pharmacy, Pharmacology Unit, University of Camerino, Via Madonna delle Carceri, 62032 Camerino (MC), Italy, E-mail: roberto.cicccocioppo@unicam.it.

DOI:10.1523/JNEUROSCI.2400-13.2014

Copyright $\odot 2014$ the authors $\quad 0270-6474 / 14 / 340363-10 \$ 15.00 / 0$
}

prolonged stress exposure, at the cost of altering normal physiological balance (McEwen and Gianaros, 2011; Schank et al., 2012). Setpoint shift involves neuroadaptations within neurocircuitry that mediate stress responses, and are influenced by several peptidergic neuromodulators. Corticotropin releasing factor (CRF) via its actions on hypothalamic and extrahypothalamic brain sites is recognized as a primary mediator of stress responses in mammals (McEwen and Gianaros, 2011; Schank et al., 2012). Other peptidergic systems, including nociceptin/orphanin FQ (N/OFQ), have been identified as important players in contrasting stress responses mediated by CRF. We previously found that N/OFQ, an opioid-like peptide that binds with high affinity to its $\mathrm{NOP}$, exerts potent functional antistress and anti-CRF actions. In particular, activation of brain NOPs by N/OFQ or other selective agonists prevents anorexia elicited by intracerebroventricular administration of CRF or by exposure to stress (Ciccocioppo et al., 2001, 2002). N/OFQ also prevents foot-shock stress-induced reinstatement of alcohol seeking (Martin-Fardon et al., 2000), whereas alcohol withdrawal in dependent animals, a condition associated with high-stress vulnerability, is associated with an increased N/OFQ and NOP gene expression in the central nucleus of the amygdala ( $\mathrm{CeA}$ ) and in the bed nucleus of the stria terminalis (Aujla et al., 2013). N/OFQ also blocks the ethanol- 
and CRF-induced increases in GABAergic transmission in the CeA (Veinante and Freund-Mercier, 1998; Roberto and Siggins, 2006; Cruz et al., 2012).

Thus, in this study, we explored the relationship between the CRF and the N/FQ systems in response to stress. We elicited stress by physically restraining rats and then measured the expression of $\mathrm{CRF}$ and N/OFQ-related genes in various subdivisions of the amygdala. We found significant and selective changes in NOP and $\mathrm{CRF}_{1}$ receptor transcript expression in the CeA and BLA of restraint rats compared with unrestraint ones. Because our gene expression results also show that CeA, but not BLA, expresses both N/OFQ and CRF, we assessed whether changes occurred in CeA GABA systems after acute physical stress restraint. Thus, focusing on the CeA we performed in vitro electrophysiological recordings to explore the interactions between N/OFQ and CRF and possible neuroplastic changes in the two peptidergic systems induced by restraint stress. Finally, we investigated the effect of NOP manipulation in the CeA on the elevated plus maze (EPM) test in rats subjected to body restraint and in unrestraint controls.

\section{Materials and Methods}

Subjects. Male Wistar rats $(N=108$, Charles River) weighing 250-300 g at the beginning of the experiments were used. Animals were housed in standard cages, in a room with artificial 12:12 h light/dark cycle (lights off at 8:00 A.M.) at constant temperature $\left(20-22^{\circ} \mathrm{C}\right)$ and humidity $\left(45-55^{\circ}\right)$, with food and water ad libitum. Rats were handled once a day for $5 \mathrm{~min}$ during the first week after arrival to the vivarium. All procedures were conducted during the dark cycle and met the guidelines of the European Community Council Directive for Care and Use of Laboratory Animals and The Scripps Research Institute Institutional Animal Care and Use Committee and National Institutes of Health guidelines on the care and use of laboratory animals.

Intracranial surgery and histological analysis. For intracranial surgery, animals were anesthetized by intramuscular injection of $100-150 \mu \mathrm{l}$ of a solution containing tiletamine chlorohydrate $(58.17 \mathrm{mg} / \mathrm{ml})$ and zolazepam chlorohydrate $(57.5 \mathrm{mg} / \mathrm{ml})$. To reach the CeA, guide cannulae were implanted bilaterally using the following coordinates with reference to Bregma: CeA, anteroposterior -1.8 ; lateral \pm 3.9 , and ventral -7.0 (Paxinos and Watson, 1998). For intracranial injection, N/OFQ was dissolved in artificial CSF (ACSF) and given bilaterally as nmol doses into the CeA in a volume of $0.5 \mu \mathrm{l} /$ site by means of a stainless-steel injector 1.5 $\mathrm{mm}$ longer than the guide cannula, so that its tip protruded into the area. After the experiments, to verify the cannula placement, $0.5 \mu \mathrm{l} / \mathrm{site}$ of black India ink was injected into the CeA immediately before the rat was euthanized, and ink diffusion into the CeA was histologically evaluated. Animals $(N=3)$ with wrong placed cannulae were excluded from the analysis.

Drugs. Nociceptin/orphanin FQ (Phe-Gly-Gly-Phe-Thr-Gly-Ala-ArgLys-Ser-Ala-Arg-Lys-Leu-Ala-Asp-Glu) (N/OFQ) and [Nphe1]-nociceptin(1-13)NH2 were purchased from Tocris Bioscience. CGP 55845A was a gift from Novartis Pharma. DL-AP5, DNQX, picrotoxin, and bicuculline were obtained from Sigma, whereas CRF was purchased from Chempacific.

Acute restraint stress. For the acute restraint stress, male Wistar rats were restrained, for $1 \mathrm{~h}$ in a cylindrical tube made of clear Plexiglas measuring 21.5-cm-long, $6.3 \mathrm{~cm}$ internal diameter. Restraint tubes were round slotted Plexiglas cylinders with sliding plugs to allow adjustment of the tube length for each animal size. The end of the tube had a sliding plastic plug that was secured in place by a screw and adjusted to fit the size of the rat. A slotted opening in the plug allowed for free mobility of the tail. For behavioral studies, animals were divided in two groups. The first one was then sorted into three smaller groups $(N=7$ or 8 per group $)$ and received N/OFQ $(0.5$ or $1.0 \mathrm{nmol} / \mathrm{rat})$ or vehicle $(0.0 \mathrm{nmol} / \mathrm{rat}) 5 \mathrm{~min}$ before they were immobilized in the restraint tube. They were restrained for $1 \mathrm{~h}$ and then returned to their home cages. Six hours later, their anxiety-like behavior was measured on the EPM, for $5 \mathrm{~min}$. The same identical procedure was performed for the control/nonrestraint rats ( $N=7$ or 8 per group).
For the electrophysiological $(N=28)$ and ISH $(N=16)$ studies, the same procedure was performed to stress the animals. The recordings from the slices were made $6 \mathrm{~h}$ later. The control rats (not subjected to the restraint stress) were euthanized at the same time of the day as the acutely restraint animals. For the ISH study, the animals were euthanized $6 \mathrm{~h}$ after the stress procedure.

EPM. The EPM is a widely used test of anxiety-like behavior, which is sensitive to anxiogenic and anxiolytic drugs (Pellow et al., 1985). We used this test to study the effect of N/OFQ on anxiety-like responses in restraint versus unrestraint animals (controls). All behavioral testing took place in a dimly lit room. The apparatus consisted of four black wooden arms (50 cm long $\times 10 \mathrm{~cm}$ wide), arranged such that the respective closed and open arms were opposite to each other. The maze, elevated $50 \mathrm{~cm}$ above the floor, was cleaned with water and dried after each trial. The 5 min test procedure began when the animals were individually placed in the center of the maze, facing a closed arm. A rat was considered to be on the central platform when at least two of its paws were on it. An entry was defined as the presence of all four paws in the arms. Percentage of time spent in open arms [\% OAT = (time in open arm/time in "open arm" + time in "closed" arm $) \times 100]$ and percentage of open arm entries [\% OAE = (number of open arm entries/number of "open + closed" arm entries) $\times$ $100]$ were considered as an index of anxiety, and the number of total arm entries was used as a measure of spontaneous locomotor activity.

$I S H$. Six hours after restraint stress, rats were rapidly decapitated. Brains were quickly removed, snap frozen in $-40^{\circ} \mathrm{C}$ isopentane, and stored at $-70^{\circ} \mathrm{C} ; 10 \mu \mathrm{m}$ coronal brain sections were taken at Bregma levels according to the atlas of Paxinos and Watson (1998) and stored at $-70^{\circ} \mathrm{C}$ until use. Specific rat riboprobes for N/OFQ (gene reference sequence in PubMed database: NM_013007, position 275-535 bp), NOP (gene reference sequence in PubMed database: NM_031569, position 879-1142 bp), CRF (gene reference sequence in PubMed database: NM_031019, position 590-748 bp), and $\mathrm{CRF}_{1} \mathrm{R}$ (gene reference sequence in PubMed database: NM_030999, position 808-1318 bp) were used as previously reported (Hansson et al., 2006). Procedures for S35 labeled probes RNA probe synthesis in both antisense and sense direction and all the hybridization steps have been described in detail in (Hansson et al., 2003, 2006). For data visualization, phosphor-imaging plates (Fujifilm for BAS-5000, Fujifilm) were exposed for $48 \mathrm{~h}$ to hybridized sections. Phosphor imager (Fujifilm Bio-Imaging Analyzer Systems, BAS5000, Fujifilm) generated digital images were analyzed using MCID Image Analysis Software (Imaging Research). Regions of interest were defined by anatomical landmarks as described in the atlas of Paxinos and Watson (1998). Signal density was measured as photostimulable luminescence per millimeter squared and converted into integrated optical density values, expressed in calibration standards units ( $\mathrm{nCi} / \mathrm{g})$ using a C14 standard curve (Microscale C14, GE Healthcare). For detailed visualization, films (Kodak BioMax MR, Eastman Kodak Company) were subsequently exposed for 1 month to hybridized sections.

Electrophysiology. The brain slices were prepared $3 \mathrm{~h}$ after the termination of the restraint period. Electrophysiological recordings were done between 5 and $7 \mathrm{~h}$ from restraint.

Slice preparation. CeA slices were prepared as previously described (Ciccocioppo et al., 2004) from 41 male Wistar rats $(264.2 \pm 17 \mathrm{~g}$ ) that were anesthetized with isoflurane (3\%) and decapitated. The brains were rapidly removed and placed into ice-cold ACSF equilibrated with $95 \%$ $\mathrm{O}_{2}$ and $5 \% \mathrm{CO}_{2}$.

Transverse, $400-\mu \mathrm{m}$-thick slices were cut on a Vibratome Series 3000 (Technical Products International), incubated in an interface configuration for $\sim 20 \mathrm{~min}$, and subsequently completely submerged and continuously superfused (flow rate of $2-4 \mathrm{ml} / \mathrm{min}$ ) with warm $\left(31^{\circ} \mathrm{C}\right.$ ), gassed ACSF of the following composition in $\mathrm{mm}$ : $\mathrm{NaCl}, 130 ; \mathrm{KCl}, 3.5$; $\mathrm{NaH}_{2} \mathrm{PO}_{4}, 1.25 ; \mathrm{MgSO}_{4}-7 \mathrm{H}_{2} \mathrm{O}, 1.5 ; \mathrm{CaCl}_{2}, 2.0 ; \mathrm{NaHCO}_{3}, 24 ;$ glucose, 10 . Drugs were added to the ACSF from stock solutions to obtain known molar concentrations in the superfusate.

Electrophysiology. Neurons were recorded principally in the medial subdivision of the CeA with sharp micropipettes filled with $3 \mathrm{M} \mathrm{KCl} \mathrm{using}$ current-clamp mode. Most neurons were held near their resting membrane potential. Pharmacologically isolated $\mathrm{GABA}_{\mathrm{A}}$ receptor-mediated IPSPs were evoked by local stimulation within the CeA through a bipolar 
Table 1. N/OFQ mRNA levels in different forebrain regions of restraint and control Wistar rats ${ }^{a}$

\begin{tabular}{llll}
\hline Brain region & Treatment & nCi/g (mean \pm SEM) & $N$ \\
\hline CeA & Control & $17.81 \pm 0.94$ & 8 \\
& Restraint & $18.60 \pm 0.69$ & 6 \\
MeA & Control & $16.94 \pm 2.17$ & 8 \\
& Restraint & $15.24 \pm 2.77$ & 6 \\
BLA & Control & ND & 8 \\
& Restraint & ND & 6 \\
\hline
\end{tabular}

${ }^{a}$ Data are expressed as $n C i / g$ (mean \pm SEM); $n=6-8$ /group. Statistical analysis has been performed by Student's $t$ test. ND, Signal not detected.

stimulating electrode while superfusing the slices with the glutamate receptor blockers DNQX $(20 \mu \mathrm{M})$ and DL-2-amino-5-phosphonovalerate (DLAP5; $30 \mu \mathrm{M}$ ), and the $\mathrm{GABA}_{\mathrm{B}}$ receptor antagonist (CGP 55845A; $1 \mu \mathrm{M}$ ). Bicuculline $(30 \mu \mathrm{M})$ or picrotoxin $(50 \mu \mathrm{M})$ was often superfused at the end of the experiment to confirm the $\mathrm{GABA}_{\mathrm{A}}$ nature of the IPSP. Data were acquired with an Axoclamp-2A preamplifier (Molecular Devices) and stored for later analysis using pClamp software (Molecular Devices). To determine the experimental response parameters for each cell, we performed an inputoutput protocol consisting of a range of current stimulations (typically between 50 and $250 \mathrm{~mA} ; 0.125 \mathrm{~Hz}$ ), starting at the threshold current required to elicit an IPSP up to the strength required to elicit the maximum amplitude. The stimulus strength was maintained throughout the entire duration of the experiment. We normalized three stimulus intensities of equal steps (threshold, half-maximal, and maximal) as 1-3×. Stability of IPSPs was established by local stimulation for at least $15 \mathrm{~min}$ before beginning experiments. The synaptic responses were quantified by averaging two consecutive responses (30 s apart, i.e., 1 data point $/ \mathrm{min}$ ) and calculating the IPSP amplitude with Clampfit software (Molecular Devices). We also applied hyperpolarizing and depolarizing current steps (200 pA increments, 750 ms duration) to generate voltage-current curves. We examined paired-pulse facilitation (PPF) in each neuron using paired stimuli at $50 \mathrm{~ms}$ interstimulus intervals. The stimulus strength was adjusted such that the amplitude of the first IPSP was $50 \%$ of the maximal amplitude as determined from the input-output relationship. We calculated the PPF ratio as the second IPSP amplitude over that of the first IPSP amplitude (Roberto et al., 2003; Cruz et al., 2012). All measures were taken before CRF or N/OFQ superfusion (control), during drug superfusion (5-15 min), and after washout (20-30 min). All values are mean \pm SEM.

Statistical analysis. Behavioral data were analyzed by means of two-way ANOVA with two between-subjects factors (restraint and N/OFQ treatment). When appropriate, post hoc comparisons were performed with the Newman-Keuls tests.

For gene expression analyses, region-wise comparisons by mean of Students's $t$ test were adopted to evaluate statistical significance.

Electrophysiological data were expressed as mean \pm SEM. Statistical analysis was performed with GraphPad Prism 5.0 software (GraphPad Software). We analyzed the data using a one-way repeated measure ANOVA or two-way repeated measure ANOVA followed by a NewmanKeuls post hoc test; $p<0.05$ was considered statistically significant. In some cases, the Student's paired or unpaired $t$ test for individual means comparisons was used. Statistical significance was set at $p<0.05$.

\section{Results}

\section{Restraint stress-induced changes in N/OFQ and}

\section{CRF-related genes}

To assess the effect of stress on the regional distribution of N/OFQ, $\mathrm{NOP}, \mathrm{CRF}$, and $\mathrm{CRF}_{1} \mathrm{mRNA}$, rat brains were analyzed by ISH. The expression of N/OFQ in all areas analyzed is reported in Table 1. In general, N/OFQ mRNA distribution was similar to that previously reported in other studies with hybridization signals found at comparable levels of expression in the medial amygdala (MeA) and the CeA. In these regions, restraint stress did not induce significant variations in N/OFQ mRNA expression. The distribution density of NOP mRNA is reported in Table 2. The highest expression level was found in the MeA followed by the CeA and
Table 2. NOP mRNA levels in different forebrain regions of restraint and control Wistar rats ${ }^{a}$

\begin{tabular}{llll}
\hline Brain region & Treatment & $\mathrm{nCi} / \mathrm{g}$ (mean \pm SEM) & $N$ \\
\hline CeA & Control & $3.25 \pm 0.51$ & 8 \\
& Restraint & $5.22 \pm 0.41^{*}$ & 8 \\
MeA & Control & $8.63 \pm 0.60$ & 8 \\
& Restraint & $8.28 \pm 0.51$ & 8 \\
BLA & Control & $2.27 \pm 0.19$ & 8 \\
& Restraint & $3.66 \pm 0.27^{*}$ & 7 \\
\hline
\end{tabular}

${ }^{a}$ Data are expressed as $n \mathrm{i} / \mathrm{g}$ (mean $\left.\pm \mathrm{SEM}\right) ; \mathrm{n}=7$ or $8 /$ group. Statistical analysis has been performed by Student's $t$ test. ${ }^{*} p<0.01$, restraint versus control.

Table 3. CRF mRNA levels in different forebrain regions of restraint and control Wistar rats ${ }^{a}$

\begin{tabular}{llll}
\hline Brain region & Treatment & nCi/g (mean \pm SEM) & $N$ \\
\hline CeA & Control & $1.70 \pm 0.12$ & 6 \\
MeA & Restraint & $2.42 \pm 0.30$ & 6 \\
& Control & ND & 6 \\
BLA & Restraint & ND & 6 \\
& Control & ND & 6 \\
\hline
\end{tabular}

$\overline{{ }^{a} \text { Data are expressed as } n \mathrm{Ci} / \mathrm{g}(\text { mean } \pm \mathrm{SEM}) ; \mathrm{n}=6-8 / \text { group. Statistical analysis has been performed by Student's }}$ $t$ test. ND, Signal not detected.

Table 4. CRF1 mRNA levels in different forebrain regions of restraint and control Wistar rats ${ }^{a}$

\begin{tabular}{llll}
\hline Brain region & Treatment & $\mathrm{nCi} / \mathrm{g}($ mean \pm SEM) & $N$ \\
\hline CeA & Control & $4.72 \pm 0.29$ & 8 \\
& Restraint & $3.31 \pm 0.30^{*}$ & 8 \\
MeA & Control & $4.61 \pm 0.26$ & 8 \\
& Restraint & $3.99 \pm 0.38$ & 7 \\
BLA & Control & $8.56 \pm 0.23$ & 7 \\
& Restraint & $6.31 \pm 0.58^{*}$ & 8 \\
\hline
\end{tabular}

${ }^{a}$ Data are expressed as $\mathrm{nCi} / \mathrm{g}$ (mean $\left.\pm \mathrm{SEM}\right) ; \mathrm{n}=7$ or $8 /$ group. Statistical analysis has been performed by Student's $t$ test. ${ }^{*} p<0.01$, restraint versus control.

the BLA. When expression levels were compared between restraint and unrestraint rats, $t$ test revealed statistically significant higher expression levels in restraint rats versus controls in the $\mathrm{CeA}\left(t_{(14)}=3.02 ; p<0.01\right)$ and in the BLA $\left(t_{(13)}=4.02 ; p<\right.$ $0.01)$. No significant differences were observed in the MeA.

As shown in Table 3, detectable CRF mRNA levels were found in the CeA. However, we did not find a significant difference between restraint and unrestraint rats in the CeA. The distribution density of $\mathrm{CRF}_{1}$ mRNA is reported in Table 4 . The highest expression density was observed in the BLA followed by the CeA, and the MeA where lower but comparable levels of expression were detected. When $\mathrm{CRF}_{1}$ mRNA expression densities were compared between restraint and unrestraint rats, $t$ test revealed a significantly lower mRNA levels in the CeA $\left(t_{(14)}=3.36\right.$; $p<$ $0.01)$ and BLA $\left(t_{(13)}=3.42 ; p<0.01\right)$ of stressed animals.

\section{Basal GABAergic transmission is increased in CeA neurons from stress-restraint rats compared with unrestraint rats} Because the CeA is a brain region well known to be involved in the physiological response to stressors and our gene expression results show that CeA is the only amygdala nucleus expressing both N/OFQ and CRF and their respective receptors, we assessed whether changes occurred in CeA GABA systems after acute physical stress restraint. We performed all the in vitro electrophysiological experiments in the CeA slices from either restraint or unrestraint control rats. We recorded from $105 \mathrm{CeA}$ neurons with mean resting membrane potential of $-76.7 \pm 1.9 \mathrm{mV}$ and $\mathrm{a}$ 
A

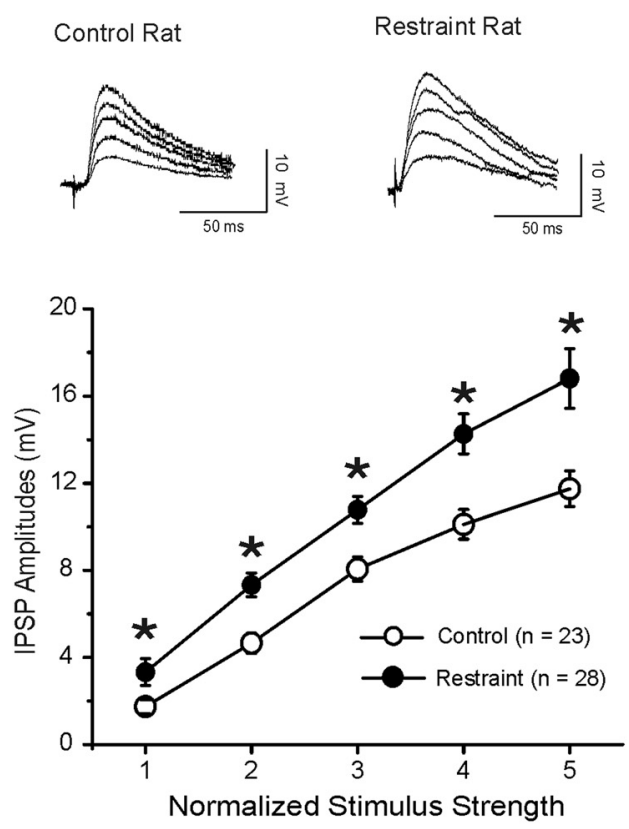

B

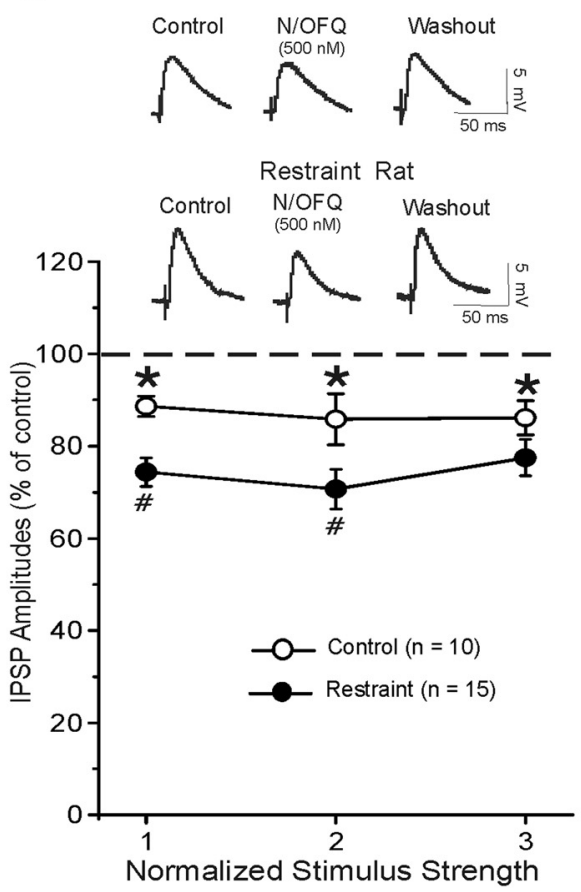

C
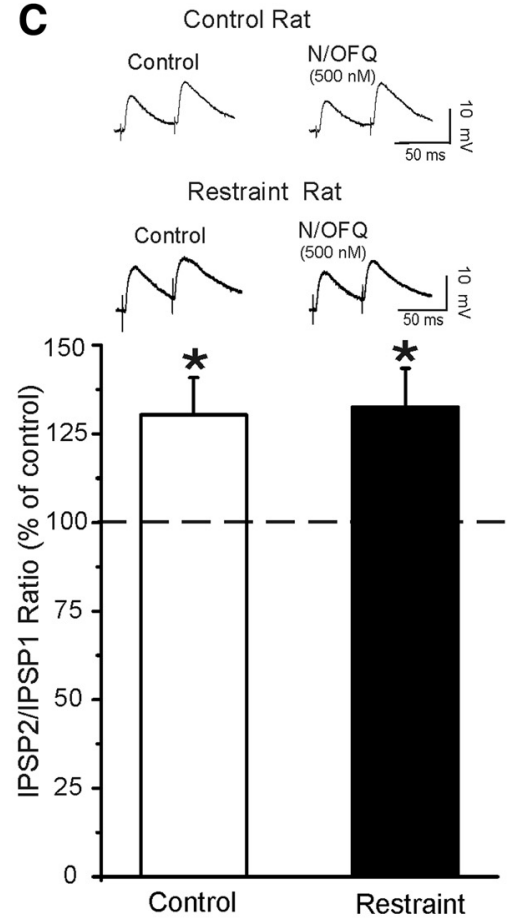

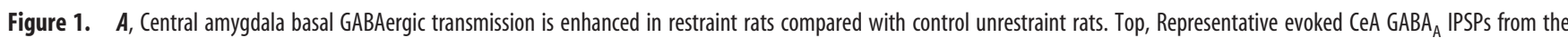
input- output curves generated in control and restraint rats. Bottom, Input- output curves of mean $G A B A_{A} I P S P$ amplitudes. The IPSPs are larger in restraint rats using five equivalent stimulus intensities. The mean baseline GABAergic transmission is significantly increased in slices from restraint rats $(n=21)$ compared with unrestraint rats $(n=17):{ }^{*} p<0.05$ (unpaired $t$ test). $\boldsymbol{B}$, Top, Representative evoked (eA IPSPs from control and restraint rats during the control, $500 \mathrm{~nm} \mathrm{N/OFQ} \mathrm{application} \mathrm{and} \mathrm{washout.} \mathrm{Bottom,} \mathrm{A} \mathrm{total} \mathrm{of} 500 \mathrm{~nm} N / 0 \mathrm{FQ}$ significantly $\left({ }^{*} p<0.05\right.$ ) decreases the mean IPSP amplitudes of evoked IPSP over the middle three stimulus strength intensities tested. The N/OFQ-induced inhibition of IPSP amplitudes is larger ( $\# p<0.05$ ) in CeA of restraint compared with unrestraint rats. C, Top, Representative PPF of evoked CeA IPSPs from control and restraint rats during control and $500 \mathrm{~nm}$ N/OFQ application. Bottom, Histograms representing percentage increase in mean \pm SEM PPF ratios of IPSPs using 50 ms interstimulus interval in CeA of control and restraint rats. N/OFQ significantly increased the PPF ratio in both groups: ${ }^{*} p<0.05$ (paired $t$ test).

mean input resistance of $114 \pm 5.6 \mathrm{M} \Omega$. The restraint stress procedure did not significantly affect the basic membrane properties of the CeA neurons. We evoked pharmacologically isolated $\mathrm{GABA}_{\mathrm{A}}$ receptor-mediated IPSPs by local stimulation within the CeA. Interestingly, baseline IPSP input-output curves generated by equivalent stimulus intensities were significantly $\left(F_{(1,253)}=\right.$ $5,749 ; p<0.001)$ higher in slices from restraint $(n=28)$ compared with those from unrestraint rats $(n=23$; Fig. $1 A)$, suggesting an increased GABAergic tone in neurons from animals exposed to the acute stress. In CeA neurons of restraint rats, the baseline PPF ratio of IPSPs was significantly $\left(t_{(47)}=2.700 ; p<\right.$ 0.001 , by unpaired $t$ test $)$ lower $(0.85 \pm 0.05, n=28)$ than in CeA neurons of unrestraint $(1.12 \pm 0.09 ; n=21)$ rats, suggesting increased baseline GABA release.

\section{$\mathrm{N} / \mathrm{OFQ}$ inhibition of GABAergic transmission is greater in restraint rats compared with unrestraint rats}

We previously reported that N/OFQ decreased the amplitudes of evoked IPSPs in CeA GABAergic synapses from naive Sprague Dawley rats via a decrease in GABA release (Roberto and Siggins, 2006). Consistent with this earlier report, here we found that 500 nM N/OFQ significantly $(p<0.05)$ reduced the amplitudes of evoked IPSPs to $87.0 \pm 0.9 \%$ of control (Fig. $1 B ; n=10$ ) in CeA from naive Wistar rats over all stimulus strengths. To assess whether the site of action was presynaptic, we examined PPF of IPSPs. Generally, changes in PPF are inversely related to transmitter release (Jensen et al., 1994), such as an increase in PPF ratio suggests decreased GABA release and vice versa. N/OFQ significantly $\left(t_{(9)}=2.290 ; p<0.05\right)$ increased the PPF ratio of IPSPs to $130.5 \%$ of control (control $1.16 \pm 0.14, \mathrm{~N} / \mathrm{OFQ} 1.44 \pm 0.16, n=$
10; Fig. 1C), suggesting that N/OFQ decreases GABA release. Then we assessed whether acute restraint stress induced relevant alterations in the N/OFQ effects on GABAergic transmission in the CeA. Interestingly, in $15 \mathrm{CeA}$ neurons from restraint rats, the N/OFQ-induced inhibition of evoked IPSP amplitudes was significantly [two-way repeated-measures ANOVA (stress restraint $\times$ drug $)$ ], $F_{(1,23)}=9.56$; $\left.p<0.05\right]$ larger $(\sim 25 \%)$ compared with the inhibition $(\sim 13 \%)$ observed in control unrestraint animals $(n=10$; Fig. $1 B)$. In CeA of restraint rats, the baseline PPF ratio of IPSPs was $0.94 \pm 0.07$, lower than in naive $(1.16 \pm 0.1)$ rats, suggesting increased baseline GABA release. N/OFQ also significantly $\left(t_{(11)}=2.352 ; p<0.05 ; n=12\right)$ increased the PPF ratio of IPSPs to $132.5 \%$ of control (restraint: baseline $0.94 \pm 0.07$; N/OFQ $1.25 \pm 0.18, n=12$; Fig. $1 C$ ).

\section{N/OFQ inhibits the CRF-induced increase in GABAergic transmission}

Next, we examined the effect of acute CRF (200 nM, a maximally effective concentration) (Roberto et al., 2010) application in CeA of naive rats. In agreement with previous studies, we found that CRF significantly $(p<0.05)$ and reversibly increased to $128.2 \pm$ $2.9 \%$ (Fig. $2 A ; n=10$ ) of the mean amplitude of evoked IPSPs measured over all stimulus strengths. This CRF-induced increase in IPSP amplitudes was associated with a significant $\left(t_{(7)}=3.916\right.$; $p<0.05$ ) decrease in PPF ratios (naive: baseline 1.21 \pm 0.2 ; CRF $0.6 \pm 0.10, n=8$; Fig. $2 D$ ).

In another set of experiments, we tested the CRF-N/OFQ interaction at the CeA GABAergic synapses from control rats, applying first CRF alone and then with N/OFQ. Superfusion of 200 nM CRF significantly $(p<0.05)$ increased to $138.2 \pm 3.7 \%$ (Fig. 
A

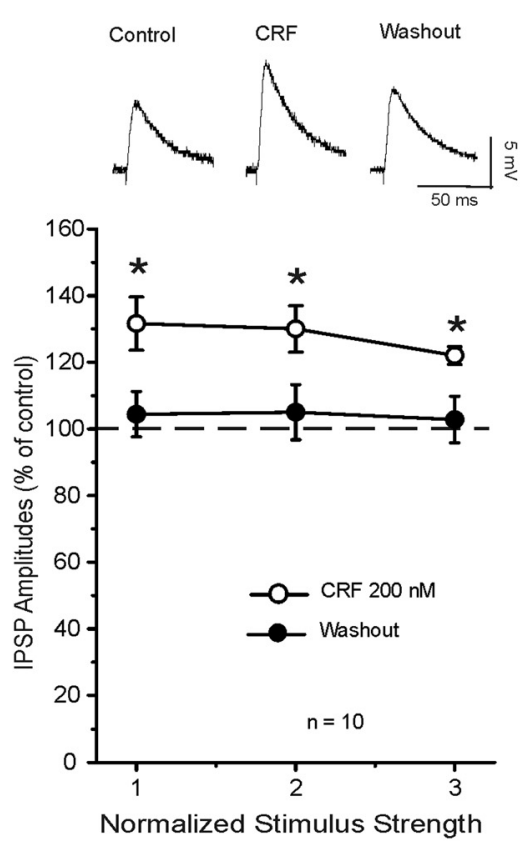

B
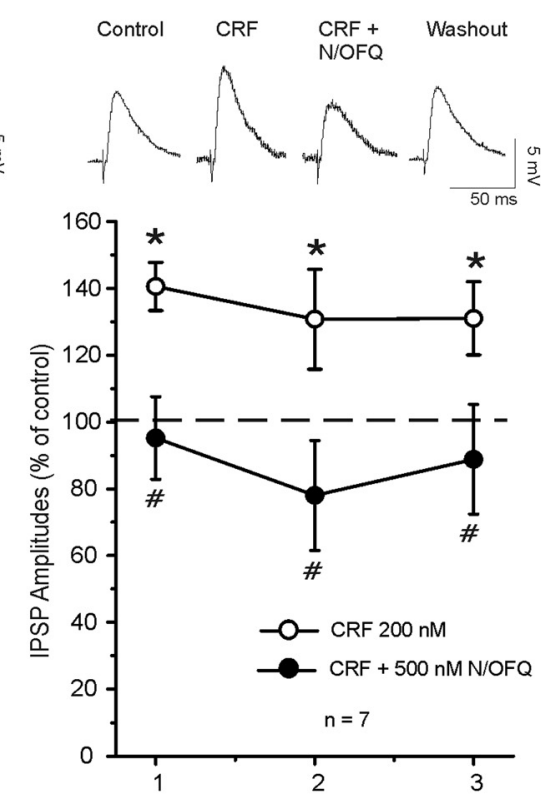

Normalized Stimulus Strength
C
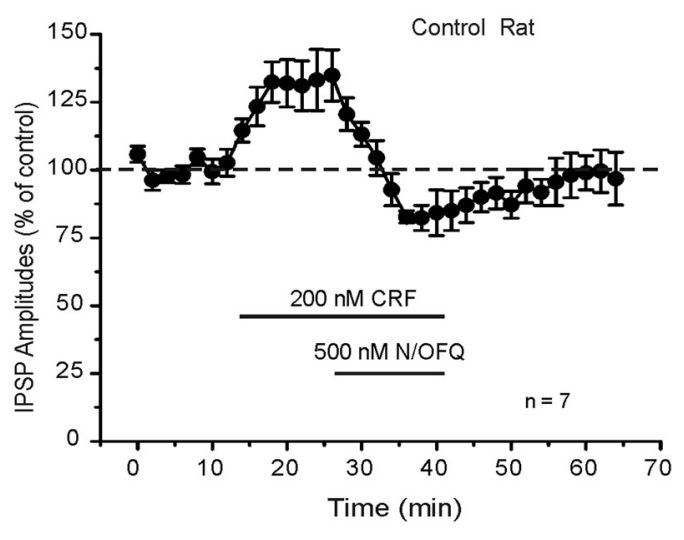

E

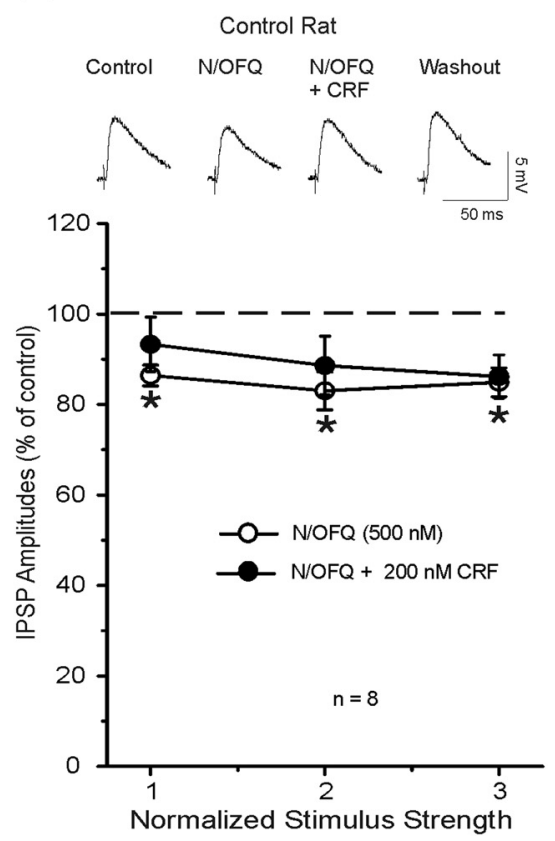

Figure 2. A, Top, Representative evoked CeA IPSPs from a control unrestraint rat during control, CRF, and washout. Bottom, CRF application reversibly and significantly increased the IPSP amplitude in CeA neurons of control rats: ${ }^{*} p<0.05$. B, Top, Representative recordings of evoked IPSPs during CRF, CRF $+N / 0 F Q$, and washout of the two peptides. Bottom, CRF significantly ${ }^{*} p<$ 0.05 ; Newman-Keuls post hoc) increases mean IPSP amplitudes and subsequent application of N/OFQ significantly ( ${ }^{\#} p<0.05$; Newman-Keuls post hoc) diminishes the (RF-induced enhancement. C, Time course of changes in evoked IPSP amplitude (at half-maximal intensity) induced by CRF, concurrent application of N/OFQ, and washout of the two peptides. D, Histograms summarized the percentage change in mean ( \pm SEM) PPF ratio of IPSPs in the experimental conditions of $\boldsymbol{A}, \boldsymbol{B}$, and $\boldsymbol{E}$. CRF significantly decreases the PPF ratio of IPSPS: ${ }^{*} p<0.05$ (Newman-Keuls post hoc). ${ }^{*} p<$ 0.05 , significance between (RF alone and concurrent application of CRF and N/OFQ (Newman-Keuls post hoc). N/OFQ significantly increases PPF ratios compared with control ${ }^{*} p<0.05$; Newman-Keuls post hoc), and (RF coapplied with N/OFQ did not alter these PPF ratios. $E$, In the (eA of control rats, N/OFQ 500 nm significantly $\left({ }^{*} p<0.05\right.$; Newman-Keuls post hoc) decreases the mean IPSP amplitudes, whereas subsequent CRF $200 \mathrm{~nm}$ has no effect.

$2 B ; n=7)$ the mean amplitude of evoked IPSPs measured over all stimulus strengths. N/OFQ (500 nM) added to the ACSF containing CRF reversed the CRF-induced augmentation and reduced the mean evoked IPSP amplitude to $86.5 \pm 2.8 \%$ of control with recover upon washout (Fig. $2 B, C$ ). The ability of N/OFQ to reverse the CRF-induced increase in IPSPs correlated with a significant increase in the PPF ratio (Fig. $2 D$ ). Specifically, CRF decreased the mean PPF ratio of IPSPs to $75.3 \pm 6 \%$ (baseline $1.24 \pm 0.2$; CRF $0.89 \pm 0.12$ ) and N/OFQ reversed the PPF ratio to pre-CRF values ( $1.31 \pm 0.17$; Fig. $2 D)$.

Because N/OFQ counteracted the effects of CRF, we then inverted the order of peptide application and tested whether N/OFQ occluded CRF. In 8 CeA neurons of control unrestraint rats, we first applied $500 \mathrm{~nm}$ N/OFQ for $15 \mathrm{~min}$ and then added $200 \mathrm{~nm}$ CRF. Overall, ANOVA revealed a significant effect $\left(F_{(2,23)}=\right.$
19.51; $p<0.001)$, and Newman-Keuls post hoc analysis revealed that nociceptin significantly $(p<0.05)$ decreased the mean amplitude of evoked IPSPs over all the stimulus intensities, and subsequent coapplication of CRF did not alter these amplitudes (Fig. 2E). Specifically, N/OFQ reduced the amplitude of evoked IPSPs to $\sim 85.4 \pm 1.5 \%$ of control over all stimulus strengths and completely prevented the CRF-induced enhancement of IPSPs $(84.6 \pm 2.6 \%, n=8$; Fig. $2 E)$. Overall, ANOVA revealed a significant effect $\left(F_{(2,6)}=6.07951 ; p<0.001\right)$, with nociceptin significantly ( $p<0.05$ by Newman-Keuls post hoc test) increasing the PPF ratios of IPSPs. Subsequent application of CRF in the presence of nociceptin did not ( $p>0.05$ by Newman-Keuls post hoc test) alter these ratios (Fig. $2 D$ ).

Then we assessed whether nociceptin would block the CRF effects in CeA of restraint rats. In $17 \mathrm{CeA}$ neurons from restraint rats, 
A
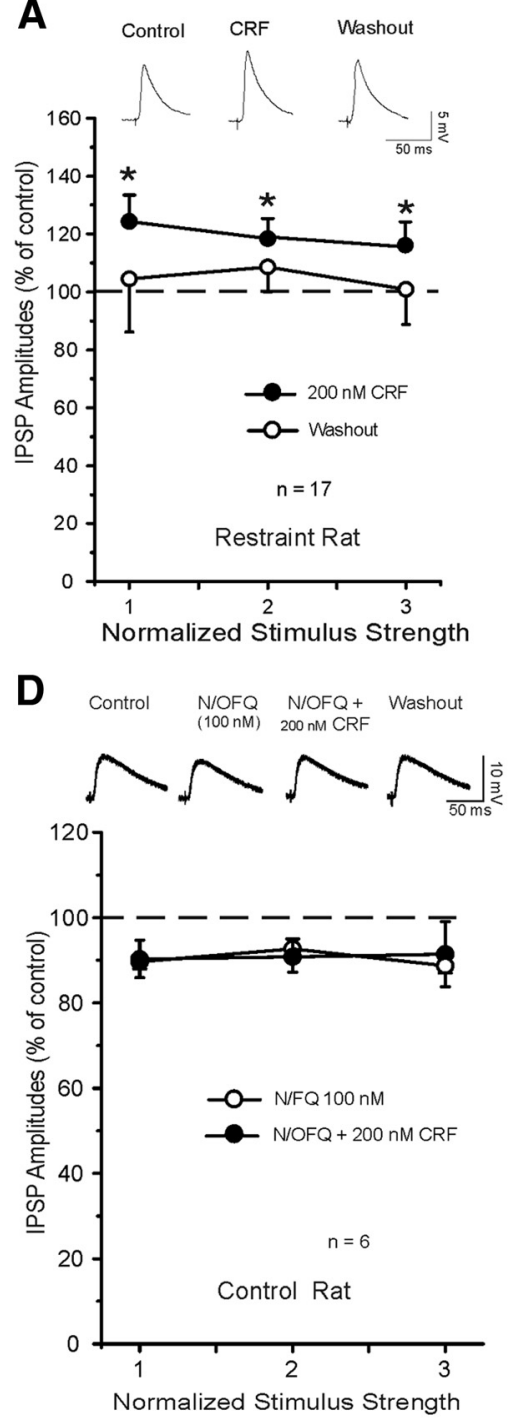

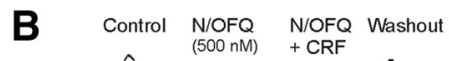

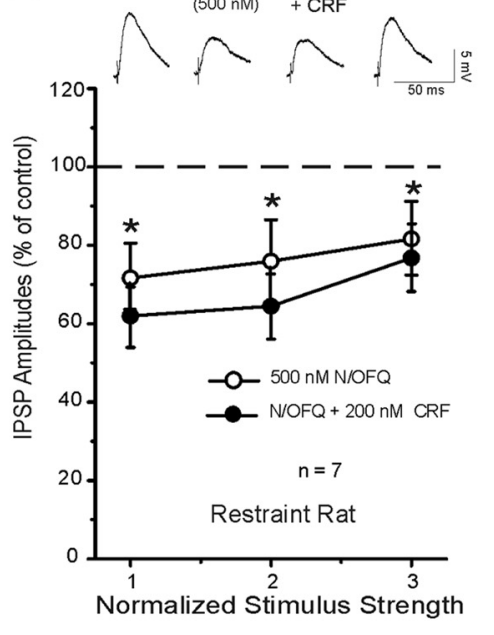

C

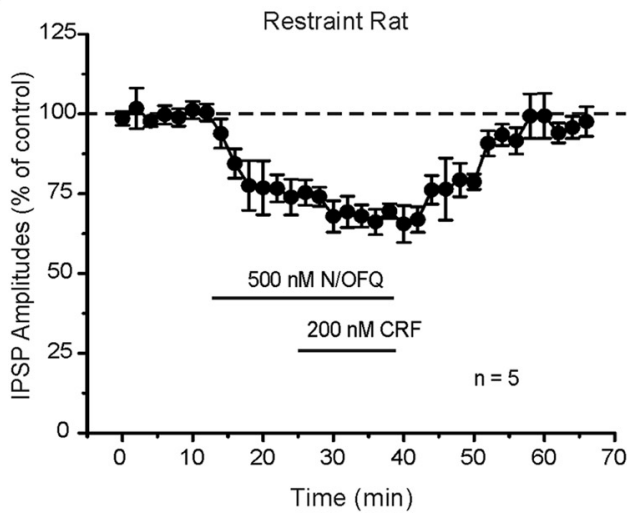

E Control $\begin{array}{lc}\mathrm{N} / \mathrm{OFQ} & \mathrm{N} / \mathrm{OFQ}+ \\ (100 \mathrm{nM}) & 200 \mathrm{nM} \mathrm{CRF}\end{array}$
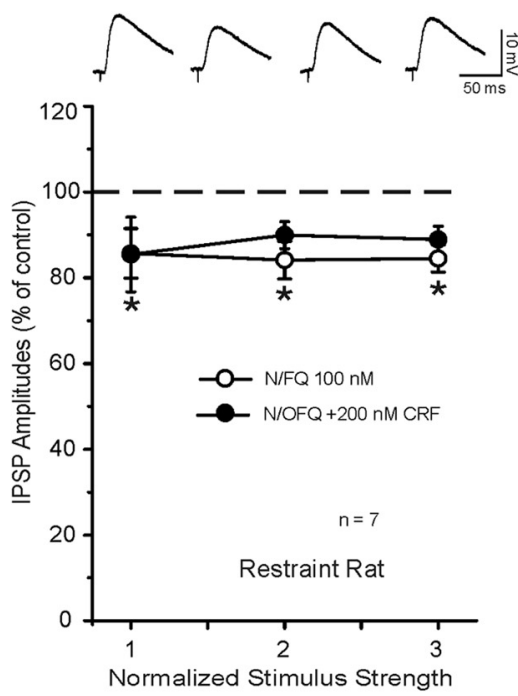

$\mathbf{F}$

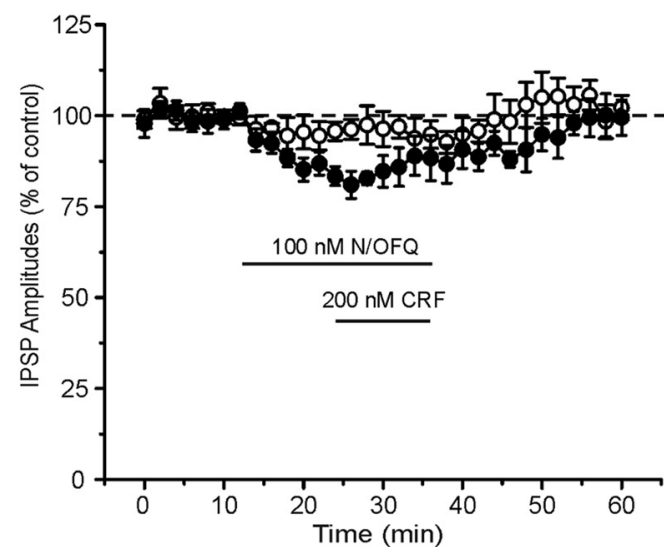

Figure 3. $\boldsymbol{A}$, In the CeA from restraint rats, superfusion of CRF alone significantly increased the mean IPSP amplitudes to $120 \%$ of control (similar to control rats): ${ }^{*} p<0.05$ (paired $t$ test). $\boldsymbol{B}$, Top, Representative evoked CeA IPSPs from a restraint rat during the N/OFQ, coapplication with CRF, and washout. Bottom, Superfusion of N/OFQ alone significantly decreased the mean IPSP amplitudes to $74 \%$ of control and prevented the enhancement of IPSPs induced by subsequent CRF (as unrestraint rats, $\boldsymbol{E}$ ): ${ }^{*} p<0.05$. C, Time course of the changes in evoked IPSP amplitude induced by N/0FQ, concurrent application of CRF, and washout of the two peptides in CeA of restraint rats. D, Top, Representative IPSPs during application of evoked CeA IPSPs from unrestraint rat during the $100 \mathrm{~nm}$ $\mathrm{N} / \mathrm{OFQ}$, coapplication with CRF, and washout. Bottom, Superfusion of $100 \mathrm{~nm}$ N/OFQ alone did not affect the mean IPSP amplitudes, but it prevented the enhancement of IPSPs induced by CRF. E, Top, Representative IPSPs during application of evoked CeA IPSPs from a restraint rat during the $100 \mathrm{~nm} \mathrm{N/OFQ,} \mathrm{coapplication} \mathrm{with} \mathrm{CRF,} \mathrm{and} \mathrm{washout.} \mathrm{Bottom,} \mathrm{Superfusion} \mathrm{of} 100 \mathrm{~nm}$ N/OFQ alone significantly decreased the mean IPSP amplitudes and blocked the CRF-induced increase of IPSPS: ${ }^{*} p<0.05$ (Newman-Keuls post hoc). $\boldsymbol{F}$, Time course of changes in evoked IPSP amplitude (at half-maximal intensity) induced by N/OFQ, concurrent application of (RF, and washout of the two peptides in the control $(n=6)$ and restraint $(n=7)$ rats.

we first tested the effect of acute CRF application alone. We found that CRF significantly $(p<0.05)$ and reversibly increased the evoked IPSP amplitude by $20 \%$, over all the stimulus intensities (Fig. $3 A$ ). Although this CRF-induced increase in GABAergic responses was slighter smaller, it was not significantly different from the one observed in unrestraint rats (Figs. $2 A$ and $3 E$ ). CRF also reversibly and significantly $\left(t_{(9)}=2.752 ; p<0.05\right)$ decreased PPF ratio of IPSPs from $0.96 \pm 0.06$ to $0.80 \pm 0.06$ (data not shown), suggesting a presynaptic effect on GABA release.

In another set of $7 \mathrm{CeA}$ neurons from restraint rats, we examined the interaction of the two peptides applying nociceptin and then CRF in the presence of nociceptin. Overall, ANOVA indicated a significant effect $\left(F_{(2,20)}=29.64 ; p<0.001\right)$. Post hoc analysis revealed that nociceptin significantly $(p<0.001)$ decreased (to $74.3 \pm 2.0 \%$ of control) the evoked IPSPs over all three stimulus intensities. Subsequent coapplication of CRF with nociceptin did not alter $(p>0.05)$ IPSP amplitudes $(67.5 \pm 4.2 \%$ of control, $n=7$; Fig. $3 B, C$ ), suggesting blockade of the CRFinduced enhancement of IPSPs. This effect was reversible upon washout. N/OFQ also increased the mean PPF ratio of IPSPs to $135.4 \pm 13 \%$ (baseline $1.06 \pm 0.2$; N/OFQ $1.45 \pm 0.16 ; n=5$ ) and blocked the CRF-induced increase of PPF ratio $(1.33 \pm 0.25)$ (data not shown). In 4 separate CeA neurons of restraint rats, we found that longer $(25 \mathrm{~min}$ ) application of nociceptin alone produced a persistent decrease $(73.8 \pm 4.6 \%$ at $15 \mathrm{~min}$ and $71.2 \pm$ $5.3 \%$ at $25 \mathrm{~min} ; n=4)$ in the IPSP amplitudes that returned to baseline levels $25 \mathrm{~min}$ into washout (data not shown).

Because nociceptin strongly opposes CRF effects at GABAergic CeA synapses, we tested whether a low (100 nM) concentration of nociceptin could antagonize an efficacious dose of CRF in both unrestraint and restraint rats. Nociceptin did not significantly affect $(p>0.05)$ baseline-evoked IPSP amplitudes in con- 
A
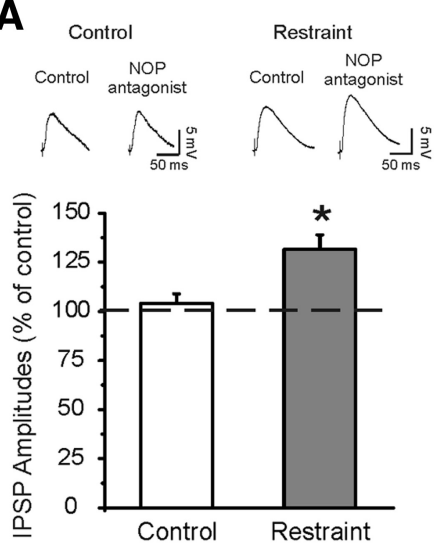

B

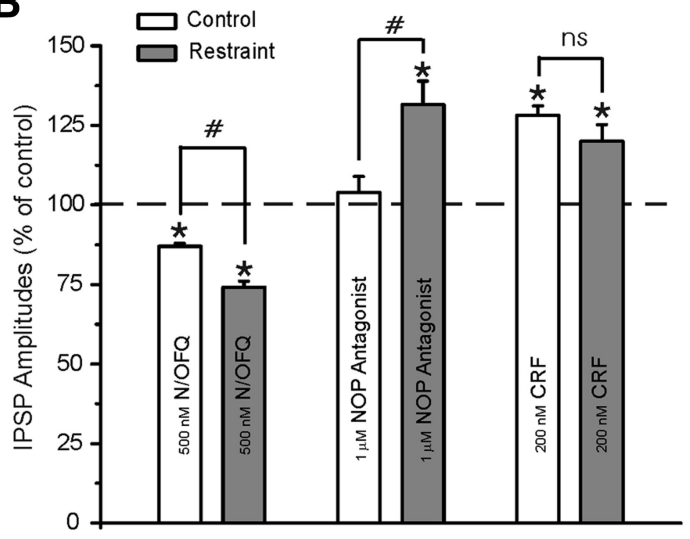

Figure 4. $\quad \boldsymbol{A}$, Top, Representative IPSPs during application of an NOP antagonist ([Nphe1]nociceptin(1-13)NH2) at $1 \mu \mathrm{M}$ concentration. Bottom, The NOP antagonist does not alter the basal-evoked IPSP amplitudes (stimulus intensity equal to halfmaximal IPSP amplitude) in control rats, but significantly increases their amplitudes in (eA neurons of restraint rats: ${ }^{*} p<0.05$ (paired $t$ test). $\boldsymbol{B}$, Histograms summarized the percentage change in mean ( \pm SEM) evoked IPSP amplitudes measured during N/OFQ, NOP antagonist, and CRF application in CeA of control and restraint rats. ${ }^{*} p<0.05$, significance between drug effects in the two animal groups. ${ }^{*} p<0.05$, significance between drug effects and baseline control within the same group. ns, Not significant.

$0.2559 ; p=0.8$; by unpaired $t$ test) different from the CRF-induced facilitation $(128.2 \pm 2.9 \%, n=10)$ of IPSPs observed in absence of the NOP antagonist.

Figure $4 B$ summarizes the main effects of $500 \mathrm{~nm}$ N/OFQ, $1 \mu \mathrm{M}$ [Nphe1]-nociceptin(1-13)NH2, and $200 \mathrm{~nm}$ CRF in both control unrestraint and restraint rats. In restraint rats, the effects of both N/OFQ and a NOP antagonist are significantly different from that in control unrestraint rats, suggesting an upregulation of this system.

\section{Effect of intra-CeA injection of N/OFQ on stress-induced increase in anxiety-like behavior}

To provide additional functional correlates for the interaction between stress and NOPs in CeA, we microinjected N/OFQ directly into the CeA of restraint and unrestraint rats. Six hours after restraint

trol unrestraint naive rats (Fig. $3 D, F$ ), but it still prevented the CRF-induced increase of evoked IPSPs. Interestingly, in CeA neurons from restraint rats, $100 \mathrm{nM}$ nociceptin significantly $\left(F_{(2,20)}=24.44 ; p<0.001\right)$ decreased baseline-evoked IPSPs to $84.7 \pm 2.5 \% \%$ of control over all three stimulus intensities (Fig. $3 E, F)$. Coapplication of CRF (200 nM) with N/OFQ did not affect $(p>0.05)$ the IPSP amplitudes compared with the application of N/OFQ alone. Nociceptin did not alter the $50 \mathrm{~ms}$ PPF ratio of IPSPs (unrestraint rats: baseline $1.02 \pm 0.09$; N/OFQ: $1.1 \pm$ $0.08 ; \mathrm{N} / \mathrm{OFQ}+\mathrm{CRF}: 1.13 \pm 0.1 ; n=6$ and restraint rats: baseline $0.73 \pm 0.08$; N/OFQ: $0.88 \pm 0.07 ; \mathrm{N} / \mathrm{OFQ}+\mathrm{CRF}: 0.83 \pm 0.1 ; n=$ 7; data not shown).

Because in CeA of restraint rats, the N/OFQ inhibitory effect on GABAergic synapses is larger and there is a significant increment of NOP expression compared with control rats, we determined whether NOPs regulate baseline evoked GABAergic transmission using a putative selective NOP antagonist, [Nphe1]-nociceptin(1-13)NH2 (Ciccocioppo et al., 2004; Roberto and Siggins, 2006; Cruz et al., 2012). Similarly to our previous studies, $1 \mu \mathrm{M}$ [Nphe1]-nociceptin(1-13)NH2 applied alone for $15 \mathrm{~min}$ had no effect (104 $\pm 5 \%$ of control; $p>0.05 ; n=6$; Fig. $4 A$ ) on basal evoked IPSPs, suggesting lack of a tonic activity of the endogenous N/OFQ transmission in CeA. Interestingly, in CeA neurons from restraint rats, the NOP antagonist significantly $(p<0.05$; $n=6$ ) increased the evoked IPSP amplitudes to $131.5 \pm 7.4 \%$ of control (Fig. 4A).

In our recent studies (Cruz et al., 2012), we reported that application of the $\mathrm{CRF}_{1}$ antagonist R121919 (1 $\left.\mu \mathrm{M}\right)$ slightly decreases evoked CeA IPSP amplitudes of naive rats. Coapplication of $500 \mathrm{~nm}$ nociceptin significantly decreases evoked IPSP amplitudes, indicating that blockade of $\mathrm{CRF}_{1}$ with R121919 does not prevent nociceptin-induced decreases in GABAergic response. Here, we tested whether NOP blockade would alter the CRF-induced facilitation of GABAergic transmission in CeA of unrestraint rats. In CeA neurons pretreated with $1 \mu \mathrm{M}$ [Nphe1]nociceptin(1-13)NH2 for $15 \mathrm{~min}$, CRF (200 nM) significantly increased the amplitude of IPSPs to $133.2 \pm 4.4 \%$ of control $(n=$ 4 ; data not shown), ruling out noncompetitive allosteric pharmacological antagonism of NOPs. In addition, in the presence of the [Nphe1]-nociceptin(1-13)NH2, the CRF-induced facilitation $(133.2 \pm 4.4 \%, n=4)$ of IPSPs was not significantly $\left(t_{(12)}=\right.$ stress, animals were tested on EPM for anxiety as illustrated in Figure 5. Overall, ANOVA revealed significant differences between restraint rats and unrestraint controls in the percentage of time spent in open arms $\left(F_{(5,53)}=5.54 ; p<0.01\right)$ (Fig. $\left.5 A\right)$.

The Newman-Keuls post hoc test showed that restraint animals spent less time in the open arm compared with unrestraint rats $(p<0.01)$, suggesting a higher level of anxiety. After injection of $1.0 \mathrm{nmol} / \mathrm{rat}$ of N/OFQ, the time spent in the open arms of restraint rats increased ( $p<0.001)$, whereas no effect was observed in unrestraint controls (Fig. 5A). No significant effects were observed after $0.5 \mathrm{nmol} / \mathrm{rat}$ of N/OFQ. Overall, ANOVA also showed a significant effect in the percentage of open arm entries $\left(F_{(5,53)}=3.2 ; p<0.05\right)$ (Fig. $\left.5 B\right)$. Post hoc comparisons demonstrated a significantly lower level of entries after restraint stress in vehicle groups $(p<0.05)$. Intra-CeA N/OFQ significantly $(p<0.001)$ increased the number of entries in the open arms at the dose of $1 \mathrm{nmol} / \mathrm{rat}$. No effect was observed at the lower dose of the peptide. Finally, the number of closed arm entries was not affected by the restraint procedure or N/OFQ treatment (Fig. 5C).

Notably, in four rats of the restraint group, histological analysis revealed incorrect cannula placement. In two of these rats, the CeA was reached only on one side of the brain, whereas in the other two animals cannulae were placed too lateral and reached the BLA. In these four animals, N/OFQ injection did not result in changes in EPM responses, thus providing some evidence that bilateral activation of CeA NOPs is needed to achieve anxiolyticlike responses after stress exposure. In unrestraint controls, wrong cannula placement was observed in two rats. Animals with incorrect cannula placement were not included in the statistical analysis. Histological reconstruction showing correct and incorrect injections into the $\mathrm{CeA}$ is presented in Figure 6.

\section{Discussion}

Physical restraint in rodents is widely used to investigate neurobiological readaptations and pathological conditions associated with stress exposure (Glavin et al., 1994; McEwen and Magarinos, 1997). Overactivation of the extrahypothalamic CRF system has been identified as a hallmark of stress-related pathologies, including anxiety, depression, eating disorders, and addiction (Walker and Davis, 2008; Shalev et al., 2010; Gilpin, 2012). On 


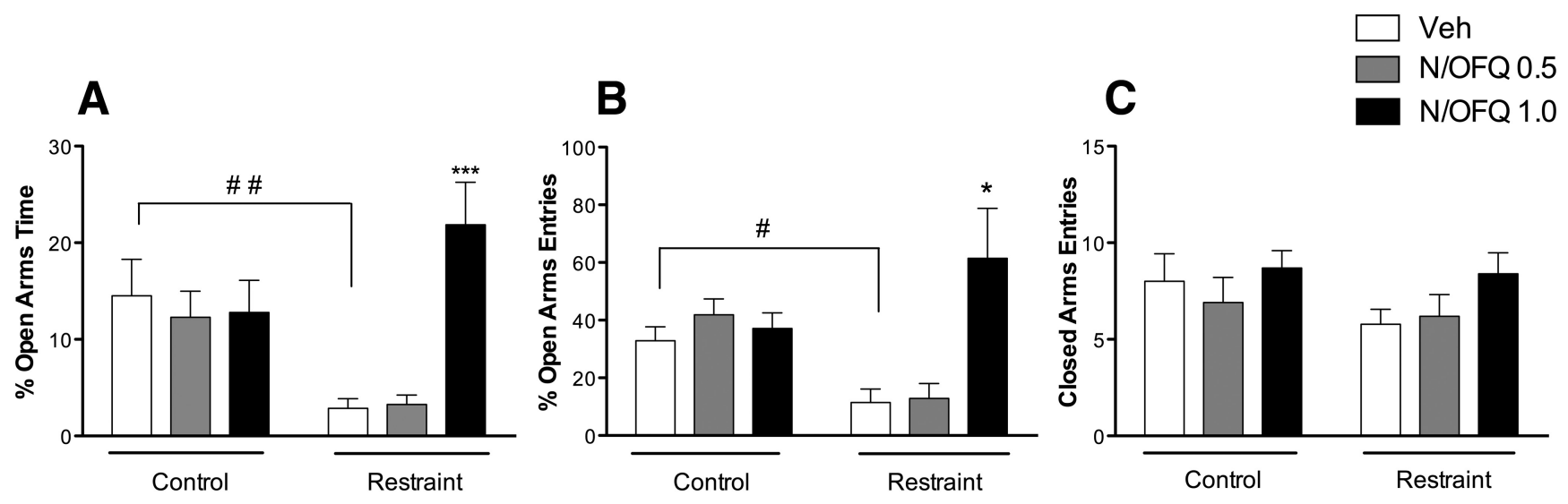

Figure 5. Effect of intra-CeA N/OFQ $\left(0.0,0.5\right.$, and $1.0 \mathrm{nmol} /$ rat) injection on EPM test. $A$, Time spent in open arms. ${ }^{\# \#} p<0.01$, Veh control versus Veh restraint (Newman-Keuls post hoc test). ${ }^{* * *} p<0.001$, N/OFQ 1.0 nmol versus Veh in the restraint group. $B$, Open arms entries. ${ }^{\#} p<0.01$, Veh control versus Veh restraint (Newman-Keuls posthoc test). ${ }^{*} p<0.05, \mathrm{~N} / 0 \mathrm{FQ} 1.0 \mathrm{nmol}$ versus Veh. $C$, Closed arm entries. The number of closed arm entries was not affected by the restraint procedure or N/OFQ treatment. In summary, our data show higher anxiety-like responses in restraint compared with unrestraint rats. N/OFQ significantly attenuated the effect of restraint stress on anxiety-like responses. Data are mean \pm SEM ( $n=9$ or 10 rats/group).

the other hand, a broad set of studies have shown that activation of the N/OFQ system may represent a mechanism through which an organism attempts to attenuate the pathological consequences arising from stress exposure (Martin-Fardon et al., 2000; Ciccocioppo et al., 2003). Based on this background, here we used physical restraint stress to investigate functional interaction between these two systems. Our attention was focused on the amygdala an area known for mediating interactions between CRF and N/OFQ neurotransmission (Ciccocioppo et al., 2003; Economidou et al., 2008).

In the ISH experiment, we found that exposure to restraint stress elicited a highly significant overexpression of NOP mRNA in the CeA and in the BLA amygdala. No differences were observed in the medial amygdala. Conversely, expression of N/OFQ transcript was not affected by restraint stress in all brain regions tested. On the other hand, the CeA and the BLA showed a reduction in $\mathrm{CRF}_{1}$ receptor gene expression after restraint. This is consistent with a scenario in which stress leads to the recruitment of the CRF system in specific brain areas, including CeA and PVN (Sterrenburg et al., 2012).

This is also in line with what we observed in the N/OFQ system in which NOP transcript overexpression may also be viewed as a physiological compensatory reaction aimed at potentiating N/OFQ signaling within the amygdala nuclei. To prove our hypothesis, we focused on the CeA. In the CeA, GABAergic neurons express CRF (Veinante et al., 1997) and CRF, like ethanol, enhances GABA release (Nie et al., 1994; Roberto et al., 2010) via activation of the $\mathrm{CRF}_{1} \mathrm{R}$, whereas N/OFQ counteracts both the CRF and ethanol effects (Roberto and Siggins, 2006; Cruz et al., 2012). Thus, here we recorded CeA GABA IPSPs in restraint and unrestraint animals and tested N/OFQ and CRF interactions. Notably, the amplitude of the baseline CeA IPSPs recorded in restraint rats was significantly elevated compared with control rats. Despite these higher baseline-evoked GABAergic responses, CRF was able to further increase them, although the CRFinduced enhancement was slightly smaller than the one observed in control unrestraint rats. In contrast to the upregulated $\mathrm{CRF}_{1} /$ CRF signaling observed in CeA of alcohol-dependent rats (Roberto et al., 2010), and as seen in the dorsal raphe after stress (Waselus et al., 2009), we report reduced $\mathrm{CRF}_{1}$ expression in CeA. Because the CRF system overall maintains its facilitatory effects on CeA GABAergic transmission of restraint rats, we speculate that reduction of $\mathrm{CRF}_{1}$ expression might also have been accompanied by compensatory post-translational changes in the $\mathrm{CRF}_{1}$ system. We also found that N/OFQ reduced the amplitudes of evoked IPSPs of control animals and prevented the CRFinduced increase of IPSPs, confirming previous findings (Cruz et al., 2012). Interestingly, we found that the depressant effect of N/OFQ on evoked IPSP amplitudes was significantly stronger in 
CeA neurons from restraint rats compared with unrestraint control animals, indicating that stress leads to an increased sensitivity of the CeA synapses to N/OFQ exogenous application. Importantly, the NOP antagonist did not alter basal evoked IPSP amplitudes in control rats but significantly increased IPSP amplitudes in restraint rats, suggesting neuroadaptations of the N/OFQ system during acute stress (i.e., increased sensitivity and expression of NOPs). We speculate that acute stress enhances tonic activity of the endogenous nociceptin/NOP system that may account for the increased sensitivity of the CeA GABA system to exogenous nociceptin. Enhancement of nociceptin-NOP function is also suggested by gene expression data indicating an increased activity of NOP system after stress. Of note, increased function of N/OFQ was also observed in alcohol-dependent rats under withdrawal, a condition associated with dysregulation of the stress system and increased CRF tone in the CeA (Roberto et al., 2010; Economidou et al., 2011; Cruz et al., 2012). Thus, the present findings together with our previous studies (Cruz et al., 2012) in ethanol-dependent rats point to a critical role of the N/OFQ system in opposing the recruitment of the CeA CRF system associated with stress-related stimuli and to restore functional equilibrium in the CeA.

Nociceptin fibers, nociceptin-containing neurons, and NOPs are widely distributed in the central amygdala (Neal et al., 1999), suggesting both local CeA production of nociceptin and from cell bodies outside the CeA. Nociceptin and CRF had opposite effects on CeA GABAergic transmission at the presynaptic level. Importantly, this interaction between peptides is more than a mere summation of opposing effects because the nociceptin-induced inhibition of GABA responses completely abolished the large amplitude increase elicited by an efficacious concentration of CRF alone. Particularly, a low (100 nM) subthreshold concentration of nociceptin did not alter baseline GABAergic responses but blocked the CRF-induced effects at these synapses in unrestraint rats. This suggests that the anti-CRF actions of nociceptin were the result of functionally independent actions and not simply the summation of opposing effects on GABAergic transmission. Interestingly, in CeA neurons from restraint rats, 100 nm nociceptin significantly decreased baseline GABA responses, supporting our hypothesis of enhanced tonic activity of the endogenous N/OFQ after exposure to acute stress.

NOP activation is known to inhibit adenylate cyclase and decrease PKA activity (via Gi protein) (Meunier, 1997). PKA is also one of the second messengers engaged by $\mathrm{CRF}_{1}$ receptor activation (via Gs and Gq proteins) (Papadopoulou et al., 2004; Cruz et al., 2012). Our recent studies demonstrated that nociceptin presynaptically preempts the action of CRF in CeA neurons via adenylate cyclase/ PKA signaling (Cruz et al., 2012). Thus, the presynaptic PKA pathway represents a common signaling pathway targeted in opposing directions by nociceptin and CRF in regulating GABA release, and the balance is tilted in favor of nociceptin, perhaps via a molecular entity upstream from CRF activation. We found specificity of the two neuropeptides at their respective receptors, such that blockade of NOP did not alter CRF-induced facilitation of GABAergic response and blockade of $\mathrm{CRF}_{1}$ did not alter N/OFQ induced inhibition of GABAergic response (Cruz et al., 2012), ruling out noncompetitive allosteric pharmacological antagonism at the level of receptors. Although the blockade of the NOP receptor by the competitive antagonist [Nphe1]-nociceptin(1-13)NH2 blocks the inhibition of the adenylate cyclase (facilitating the intracellular signaling pathway), in unrestraint rats this blockade of the NOP receptor has no significant effects on the amplitudes of basal GABAergic responses (revealing no endogenous N/OFQ tone) but is able to prevent the effect of exogenous N/OFQ by blocking receptor activation. Thus, because there is little endogenous N/OFQ tone, blockade of the NOP (which blocks the inhibition of adelylate cyclase) does not significantly affect (facilitate) the CRF-induced facilitation of GABA responses.

To further confirm the antistress properties of N/OFQ, we monitored the consequences of body restraint stress on anxiety-like behavior in the EPM test. Moreover, we studied the EPM effects of N/OFQ injected directly into the CeA, comparing peptide effects in physically restraint and unrestraint rats. Results revealed that activation of NOP in the CeA leads to a pronounced anxiolytic-like profile in restraint rats. At the same dose, no effects were detected in unrestraint controls. This finding further demonstrates that stress exposure leads to increased efficacy of N/OFQ as anxiolytic, this effect of the peptide is mediated by activation of NOPs in the CeA and is likely dependent upon the antistress action of N/OFQ. Notably, in restraint rats with incorrect cannula placement, central injection of N/OFQ did not show EPM effects, thus providing some evidence that bilateral activation on CeA NOP is needed to achieve anxiolyticlike responses after stress exposure. Another consideration is that N/OFQ did not appear to have a dose-related effect on anxiety. This is, however, not surprising because the EPM is a paradigm where dose-response relationships are not easily captured. Moreover, this finding is in line with previous studies showing that the EPM effects of N/OFQ are not dose-related (Uchiyama et al., 2008a, b; Economidou et al., 2011).

Overall, our findings are partially in agreement with a previous study in which it was shown that activation of the stress system by intracerebroventricular infusion of CRF leads to a compensatory overexpression of NOP transcript and to a heightened sensitivity to the anxiolytic-like effects of N/OFQ (Rodi et al., 2008). The electrophysiological and microinjection results clearly point to the specificity of the role of the CeA in N/OFQ function in response to restraint stress exposure. In agreement with our findings, other studies have shown that site-specific microinjection of N/OFQ into the CeA resulted in significant anxiolytic-like actions in the EPM test, supporting the anxiolyticlike effects of this peptide (Uchiyama et al., 2008b). In contrast, N/OFQ effects were observed in rodents that were not subjected to stress procedures (Uchiyama et al., 2008a). It is well known that environmental factors, such as housing conditions, have an important impact in the regulation of stress mechanisms. Hence, it is possible that, if in these latter studies animals were maintained or tested under a more stressful environment, the N/OFQ system might have been recruited as well. In support of this view, there are data showing that NOP or N/OFQ gene expression and function are upregulated after exposure to environmental stress, such as social crowding or maternal separation (Ploj et al., 2002; Reiss et al., 2007). Additional factors may have also contributed to this discrepancy in the anxiolytic effect of intra-CeA injection of N/OFQ in normal nonstressed rats. For example, here the study was conducted in Wistar rats during the dark period of the light dark cycle using a four arm elevated maze, whereas in the study by Uchiyama et al. (2008a), Sprague Dawley rats were tested during the light phase of the light dark cycle using a three arm elevated maze.

In conclusion, through a multidisciplinary approach, the present study provides converging evidence demonstrating that stress leads to an increased efficacy of NOP-mediated neuronal activity in the CeA. This change in N/OFQ neurotransmission may be viewed as an adaptive response to overactivation of the extrahypothalamic CRF system elicited by stress. In turn, changes in CRF and N/OFQ functions may contribute to the setpoint shift 
of the brain stress system leading to maladaptive responses to stress. Finally, our results indicate the potential of NOP agonism as treatment for psychiatric conditions associated with heightened CRF system activity or triggered by stress.

\section{References}

Aujla H, Cannarsa R, Romualdi P, Ciccocioppo R, Martin-Fardon R, Weiss F (2013) Modification of anxiety-like behaviors by nociceptin/orphanin $\mathrm{FQ}(\mathrm{N} / \mathrm{OFQ})$ and time-dependent changes in N/OFQ-NOP gene expression following ethanol withdrawal. Addict Biol 18:467-479. CrossRef Medline

Ciccocioppo R, Martin-Fardon R, Weiss F, Massi M (2001) Nociceptin/orphanin FQ inhibits stress- and CRF-induced anorexia in rats. Neuroreport 12:1145-1149. CrossRef Medline

Ciccocioppo R, Biondini M, Antonelli L, Wichmann J, Jenck F, Massi M (2002) Reversal of stress- and CRF-induced anorexia in rats by the synthetic nociceptin/orphanin FQ receptor agonist, Ro 64-6198. Psychopharmacology (Berl) 161:113-119. CrossRef Medline

Ciccocioppo R, Fedeli A, Economidou D, Policani F, Weiss F, Massi M (2003) The bed nucleus is a neuroanatomical substrate for the anorectic effect of corticotropin-releasing factor and for its reversal by nociceptin/ orphanin FQ. J Neurosci 23:9445-9451. Medline

Ciccocioppo R, Economidou D, Fedeli A, Angeletti S, Weiss F, Heilig M, Massi M (2004) Attenuation of ethanol self-administration and of conditioned reinstatement of alcohol-seeking behaviour by the antiopioid peptide nociceptin/orphanin FQ in alcohol-preferring rats. Psychopharmacology (Berl) 172:170-178. CrossRef Medline

Cruz MT, Herman MA, Kallupi M, Roberto M (2012) Nociceptin/orphanin FQ blockade of corticotropin-releasing factor-induced $\gamma$-aminobutyric acid release in central amygdala is enhanced after chronic ethanol exposure. Biol Psychiatry 71:666-676. CrossRef Medline

Economidou D, Hansson AC, Weiss F, Terasmaa A, Sommer WH, Cippitelli A, Fedeli A, Martin-Fardon R, Massi M, Ciccocioppo R, Heilig M (2008) Dysregulation of nociceptin/orphanin FQ activity in the amygdala is linked to excessive alcohol drinking in the rat. Biol Psychiatry 64:211-218. CrossRef Medline

Economidou D, Cippitelli A, Stopponi S, Braconi S, Clementi S, Ubaldi M, Martin-Fardon R, Weiss F, Massi M, Ciccocioppo R (2011) Activation of brain NOP receptors attenuates acute and protracted alcohol withdrawal symptoms in the rat. Alcohol Clin Exp Res 35:747-755. CrossRef Medline

Gilpin NW (2012) Corticotropin-releasing factor (CRF) and neuropeptide $\mathrm{Y}$ (NPY): effects on inhibitory transmission in central amygdala, and anxiety- and alcohol-related behaviors. Alcohol 46:329-337. CrossRef Medline

Glavin GB, Paré WP, Sandbak T, Bakke HK, Murison R (1994) Restraint stress in biomedical research: an update. Neurosci Biobehav Rev 18:223249. CrossRef Medline

Hansson AC, Sommer W, Rimondini R, Andbjer B, Strömberg I, Fuxe K (2003) c-fos reduces corticosterone-mediated effects on neurotrophic factor expression in the rat hippocampal CA1 region. J Neurosci 23:60136022. Medline

Hansson AC, Cippitelli A, Sommer WH, Fedeli A, Björk K, Soverchia L, Terasmaa A, Massi M, Heilig M, Ciccocioppo R (2006) Variation at the rat Crhrl locus and sensitivity to relapse into alcohol seeking induced by environmental stress. Proc Natl Acad Sci U S A 103:15236-15241. CrossRef Medline

Jensen BN, Jeppesen LJ, Mortensen BB, Kjaergaard B, Andreasen H, Glavind K (1994) The superiority of rectal thermometry to oral thermometry with regard to accuracy. J Adv Nurs 20:660-665. CrossRef Medline

Martin-Fardon R, Ciccocioppo R, Massi M, Weiss F (2000) Nociceptin prevents stress-induced ethanol- but not cocaine-seeking behavior in rats. Neuroreport 11:1939-1943. CrossRef Medline

McEwen BS, Gianaros PJ (2011) Stress- and allostasis-induced brain plasticity. Annu Rev Med 62:431-445. CrossRef Medline

McEwen BS, Magarinos AM (1997) Stress effects on morphology and function of the hippocampus. Ann N Y Acad Sci 821:271-284. CrossRef Medline

Meunier JC (1997) Nociceptin/orphanin FQ and the opioid receptor-like ORL1 receptor. Eur J Pharmacol 340:1-15. CrossRef Medline

Neal CR Jr, Mansour A, Reinscheid R, Nothacker HP, Civelli O, Watson SJ Jr (1999) Localization of orphanin FQ (nociceptin) peptide and messenger
RNA in the central nervous system of the rat. J Comp Neurol 406:503547. CrossRef Medline

Nie Z, Madamba SG, Siggins GR (1994) Ethanol inhibits glutamatergic neurotransmission in nucleus accumbens neurons by multiple mechanisms. J Pharmacol Exp Ther 271:1566-1573. Medline

Papadopoulou N, Chen J, Randeva HS, Levine MA, Hillhouse EW, Grammatopoulos DK (2004) Protein kinase A-induced negative regulation of the corticotropin-releasing hormone Rlalpha receptor-extracellularly regulated kinase signal transduction pathway: the critical role of Ser301 for signaling switch and selectivity. Mol Endocrinol 18:624-639. CrossRef Medline

Paxinos G, Watson C (1998) The rat brain in stereotaxic coordinates. San Diego: Academic.

Pellow S, Chopin P, File SE, Briley M (1985) Validation of open:closed arm entries in an elevated plus-maze as a measure of anxiety in the rat. J Neurosci Methods 14:149-167. CrossRef Medline

Ploj K, Roman E, Nylander I (2002) Effects of maternal separation on brain nociceptin/orphanin FQ peptide levels in male Wistar rats. Pharmacol Biochem Behav 73:123-129. CrossRef Medline

Reiss D, Wolter-Sutter A, Krezel W, Ouagazzal AM (2007) Effects of social crowding on emotionality and expression of hippocampal nociceptin/ orphanin FQ system transcripts in mice. Behav Brain Res 184:167-173. CrossRef Medline

Roberto M, Siggins GR (2006) Nociceptin/orphanin FQ presynaptically decreases GABAergic transmission and blocks the ethanol-induced increase of GABA release in central amygdala. Proc Natl Acad Sci U S A 103:97159720. CrossRef Medline

Roberto M, Madamba SG, Moore SD, Tallent MK, Siggins GR (2003) Ethanol increases GABAergic transmission at both pre- and postsynaptic sites in rat central amygdala neurons. Proc Natl Acad Sci U S A 100:20532058. CrossRef Medline

Roberto M, Cruz MT, Gilpin NW, Sabino V, Schweitzer P, Bajo M, Cottone P, Madamba SG, Stouffer DG, Zorrilla EP, Koob GF, Siggins GR, Parsons LH (2010) Corticotropin releasing factor-induced amygdala $\gamma$-aminobutyric acid release plays a key role in alcohol dependence. Biol Psychiatry 67:831839. CrossRef Medline

Rodi D, Zucchini S, Simonato M, Cifani C, Massi M, Polidori C (2008) Functional antagonism between nociceptin/orphanin FQ (N/OFQ) and corticotropin-releasing factor (CRF) in the rat brain: evidence for involvement of the bed nucleus of the stria terminalis. Psychopharmacology (Berl) 196:523-531. CrossRef Medline

Schank JR, Ryabinin AE, Giardino WJ, Ciccocioppo R, Heilig M (2012) Stress-related neuropeptides and addictive behaviors: beyond the usual suspects. Neuron 76:192-208. CrossRef Medline

Shalev U, Erb S, Shaham Y (2010) Role of CRF and other neuropeptides in stress-induced reinstatement of drug seeking. Brain Res 1314:15-28. CrossRef Medline

Sterrenburg L, Gaszner B, Boerrigter J, Santbergen L, Bramini M, Roubos EW, Peeters BW, Kozicz T (2012) Sex-dependent and differential responses to acute restraint stress of corticotropin-releasing factor-producing neurons in the rat paraventricular nucleus, central amygdala, and bed nucleus of the stria terminalis. J Neurosci Res 90:179-192. CrossRef Medline

Uchiyama H, Toda A, Hiranita T, Watanabe S, Eyanagi R (2008a) Role of amygdaloid nuclei in the anxiolytic-like effect of nociceptin/orphanin FQ in rats. Neurosci Lett 431:66-70. CrossRef Medline

Uchiyama H, Yamaguchi T, Toda A, Hiranita T, Watanabe S, Eyanagi R (2008b) Involvement of the GABA/benzodiazepine receptor in the anxiolytic-like effect of nociceptin/orphanin FQ. Eur J Pharmacol 590: 185-189. CrossRef Medline

Veinante P, Freund-Mercier MJ (1998) Intrinsic and extrinsic connections of the rat central extended amygdala: an in vivo electrophysiological study of the central amygdaloid nucleus. Brain Res 794:188-198. CrossRef Medline

Veinante P, Stoeckel ME, Freund-Mercier MJ (1997) GABA- and peptideimmunoreactivities co-localize in the rat central extended amygdala. Neuroreport 8:2985-2989. CrossRef Medline

Walker DL, Davis M (2008) Role of the extended amygdala in shortduration versus sustained fear: a tribute to Dr. Lennart Heimer. Brain Struct Funct 213:29-42. CrossRef Medline

Waselus M, Nazzaro C, Valentino RJ, Van Bockstaele EJ (2009) Stress-induced redistribution of corticotropin-releasing factor receptor subtypes in the dorsal raphe nucleus. Biol Psychiatry 66:76-83. CrossRef Medline 